\section{Alguns apontamentos feitos ao texto de Jesús Martín-Barbero "O que a pesquisa latino-americana de comunicação deve ao Brasil. Relato pessoal de uma experiência intercultural"}

Notes to the text by Jesús Martín-Barbero "What Latin American communication research owes to Brazil: Personal account of an intercultural experience"

MARIA IMMACOLATA VASSA L L DE LOPESa

Universidade de São Paulo, Programa de Pós-Graduação em Ciências da Comunicação. São Paulo, SP - Brasil

Uma forma de homenagem ao Mestre Jesús Martín-Barbero, após poucos meses de sua partida.

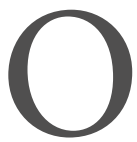

QUE SE SEGUE são breves anotações decorrentes da releitura de um texto de Jesús Martín-Barbero (JMB), originalmente apresentado em 1997, há 21 anos. O longo tempo decorrido e o momento presente criaram uma leitura especial do texto tanto pela emoção da perda recente quanto pelo tema abordado. Leio hoje esse texto como um mapa, em que JMB acabou cartografando as mais importantes contribuições brasileiras à pesquisa de comunicação na América Latina. E o leio também como uma historiografia do campo da comunicação, em seu período inicial, na década de 1980, quando o autor apenas assinalava, mas que podem agora ser claramente vistas, as inúmeras inovações que a pesquisa brasileira aportou no período e cujas ressonâncias chegam até os dias de hoje. Ainda mais, tornou-me possível seguir, no relato feito em primeira pessoa, as influências brasileiras na sua própria obra - lembrando que decorriam apenas dez anos da primeira publicação de De los Medios a las Mediaciones (1987) - tais como o aprofundamento de seu programa de estudos das relações comunicação e cultura, a aproximação da teoria das brechas com a teoria das mediações; os "tempranos" estudos sobre a competência da recepção e sobre novos modos de ver a globalização e a interculturalidade.

DOI:http://dx.doi.org/10.11606/issn.19\$2-\$160.v15i2p123-126 V.15 - № 2 mai./ago. 2021 São Paulo-Brasil MARIA IMMACOLATA VASSALLODELOPES p. 123-126
${ }^{\text {a }}$ Professora Titular Sênior da Escola de Comunicações e Artes da Universidade de São Paulo. Orcid: https://orcid. org/0000-0003-3477-1068. E-mail: immaco@usp.br 
Iniciando a cartografia, o autor identifica a pedagogia libertária de Paulo Freire - com seu programa de palavra e ação - e o conceito de hegemonia de Gramsci - com seu estudo da dominação como processo de comunicação - como os dois pilares que lhe possibilitaram pensar a comunicação, de outra maneira que não a que então imperava na pesquisa latino-americana (uma espécie de funcionalismo de esquerda), não apenas como processo de dominação, mas como processo social vivido e como campo de batalha cultural. Esses dois autores, segundo ele, lhe serviram para traçar quatro mapas das contribuições originais da pesquisa brasileira, condensados a seguir.

\section{PENSAR OS MEIOS NA FORMAÇÃO HISTÓRICA DO NACIONAL- POPULAR}

A primeira contribuição da pesquisa brasileira é identificada a partir de seu primeiro encontro com o Brasil, em setembro de 1983. E foi a descoberta de que, aqui, pensar os meios era pensar o país, era pensar para além da propriedade e das funções dos meios. A formação complexa de país, mestiçagens políticas e culturais conflitivas, a começar com as ambiguidades do populismo, as "ideias fora do lugar" e, principalmente, o debate sobre a cultura nacional-popular inauguram, segundo $\mathrm{JMB}$, os estudos modernos da cultura. Aqui encontrou abordagens diversas e inovadoras da cultura e da identidade nacionais, com grande intensidade teórica e política, e da cultura cotidiana e dos meios e neles a presença do popular.

Essas são fontes explicitamente reconhecidas para o seu conceito de popular-massivo e que lhe permitiram aproximação ao circuito de estratagemas e astúcias e de táticas, no sentido de Michel de Certeau, isto é, a cultura como campo de lutas, tendo como pano de fundo os conflitos e as contradições entre os movimentos pela afirmação da identidade nacional-popular e os movimentos de modernização de uma cultura de massas no país. São peculiaridades de uma indústria cultural regidas pelo trânsito entre lógicas distintas que têm a ver com uma modernidade cultural à brasileira. A nova ideia de nação e de identidade nacional, que se faz sob a égide de uma ideologia da integração nacional, terá na televisão o seu principal veículo e na telenovela o seu melhor discurso.

Poderia dizer que JMB, já marcado por sua futura mediação da sensibilidade, não podia deixar de notar a ausência do "mau olhado dos intelectuais" no Brasil, em contraposição a outros países latino-americanos, cuja insensibilidade marcou as relações daqueles países com os meios. Aqui, ele examina a importância da relação dos intelectuais com os meios massivos, o seu entendimento e sua configuração como indústria cultural, principalmente através da televisão. Aqui, filósofos e cientistas sociais de grande peso se voltaram para ela, como Muniz 
Sodré, Décio Pignatari, Sergio Miceli, Renato Ortiz, Sérgio Capparelli, Marlyse Meyer; escritores e artistas como Dias Gomes, Doc Comparato, Walter George Durst, Aguinaldo Silva. São autores de pesquisas e ensaios, autores e diretores de telenovelas e séries que foram decisivos para gestar as relações da televisão com o país e a capacidade de experimentação dramatúrgica e audiovisual.

\section{A CULTURA POPULAR COMO ESPAÇO DE CONTRA-HEGEMONIA COMUNICATIVA}

O segundo aporte estratégico da pesquisa brasileira de comunicação à pesquisa latino-americana foi a precoce superação da razão dualista, que, em outros países, estava impedindo de compreender a complexidade das relações entre o popular e o massivo, o que os meios têm de cultura e o que as pessoas podem fazer com eles. Suas referências são Sergio Miceli, para quem a indústria cultural brasileira ocupa um mercado material e simbólico não unificado, em que se cruzam produtos, demandas e leituras heterogêneas (o bourdieusiano estudo A Noite da Madrinha); e Roberto DaMatta, com as temporalidades e espacialidades originais da cultura brasileira ( A Casa e a Rua). A partir deles, JMB identifica, no Brasil, o avanço de duas linhas estratégicas de pesquisa: 1) a contra-hegemonia comunicativa, com pesquisas iniciais que ligavam os meios aos movimentos populares e às possibilidades da contra-informação e da hegemonia popular, além dos temas da comunicação popular e práxis de contra-informação: Luiz Beltrão, Carlos Eduardo Lins da Silva, Anamaria Fadul; os Ciclos da Sociedade Brasileira de Estudos Interdisciplinares da Comunicação (Intercom), em 1979, 1980 e 1981; e 2) a competência do sujeito receptor, com a demonstração da criatividade comunicativa das culturas populares e suas relações com os meios como cenário de lutas políticas e culturais, gestando trabalhos como os de Regina Festa e Luiz Fernando Santoro. Por outro lado, esse cenário também levou JMB a descobrir a teoria das brechas que as próprias contradições políticas abrem nas indústrias culturais: Muniz Sodré e a cultura negra revivida e cultivada até clandestinamente; Maria Immacolata Vassallo de Lopes e a voz do ouvinte de Gil Gomes que leva ao reconhecimento dos sujeitos anônimos e pobres da cidade; a outra face do receptor: Anamaria Fadul e o trabalho de recepção crítica; Mauro Wilton e a inserção da telenovela na vida de jovens trabalhadores. Na precoce atenção prestada pelos pesquisadores brasileiros à competência do receptor e à inserção desta no mundo do cotidiano, tiveram papel importante a presença pioneira de uma antropologia da cidade (Ruth Cardoso, José Guilherme Magnani); do cotidiano (Teresa Pires Caldeira, G. Velho, Everardo Rocha); da recepção de telenovela (Ondina Fachel Leal) e da recepção do Jornal Nacional 
(Carlos Eduardo Lins da Silva), investigando as mediações críticas introduzidas pela igreja, o movimento sindical, os partidos políticos, o movimento feminista. JMB assinala a grande repercussão, na América Latina, de todos esses estudos brasileiros sobre a produção e reelaboração simbólica que as classes populares fazem dos produtos midiáticos. Outra precoce experiência brasileira foi a prática da interdisciplinaridade, ao colocar juntos sociólogos, psicólogos, historiadores e comunicólogos (Seminário Sujeito, o lado oculto do receptor, 1991).

\section{GLOBALIZAÇÃO COMUNICACIONAL E MODERNIDADE-MUNDO}

Autores e trabalhos seminais são incorporados: Milton Santos e o novo sentido de espaço e tempo; Renato Ortiz e novo sentido de mundialização; Octávio Ianni e novo sentido de globalização como paradigma emergente das ciências sociais do século XXI. São tomados como exemplos de trabalhos que superavam as abordagens simplificadoras de rechaço da globalização encontradas nas pesquisas latino-americanas.

\section{APROPRIAÇÃO CRÍTICA DA PESQUISA LATINO-AMERICANA}

JMB destaca o papel da Intercom, com clara vocação latino-americanista e permanente diálogo com a pesquisa da região, citando o V Ciclo, 1982 - Impasses e desafios da pesquisa em comunicação; Teoria e pesquisa em comunicação: panorama latino-americano; a reconstituição da Alaic, em 1989, e a importância da atuação de José Marques de Melo; o I Congresso Latino-Americano de Investigadores da Comunicação, em 1992.

No diálogo particularmente fértil sobre teoria, pesquisa e ensino de Comunicação, cita Maria Immacolata Vassallo de Lopes, com sua crítica à funcionalização das pesquisas de recepção e o livro Pesquisa em Comunicação, com novos objetos e propostas de pesquisa. Porém, ele critica a visão de ensino e pesquisa ditada pelas necessidades do mercado, apontada por José Marques de Melo em textos de 1987 e 1991, o que passaria a marcar uma ruptura do autor com essa linha de pesquisa brasileira. Em conclusão, JMB endossa a voz de colegas latino-americanos ao

reconhecer a presença decisiva da pesquisa brasileira na gestação de um pensamento latino-americano sobre a comunicação que, de uma vez nos permite uma compreensão mais profunda das peculiaridades e dinâmicas do nosso mundo, e nos está possibilitando no plano internacional passar do papel de 'informante nativo' ao de verdadeiros produtores de pensamento e de conhecimentos. $\mathbf{M}$ 